\title{
Practice of breastfeeding in quilombola communities in the light of transcultural theory
}

\author{
Prática do aleitamento materno em comunidades quilombolas à luz da teoria transcultural \\ Práctica del alcance materno en comunidades quilombolas a la luz de la teoria transcultural
}

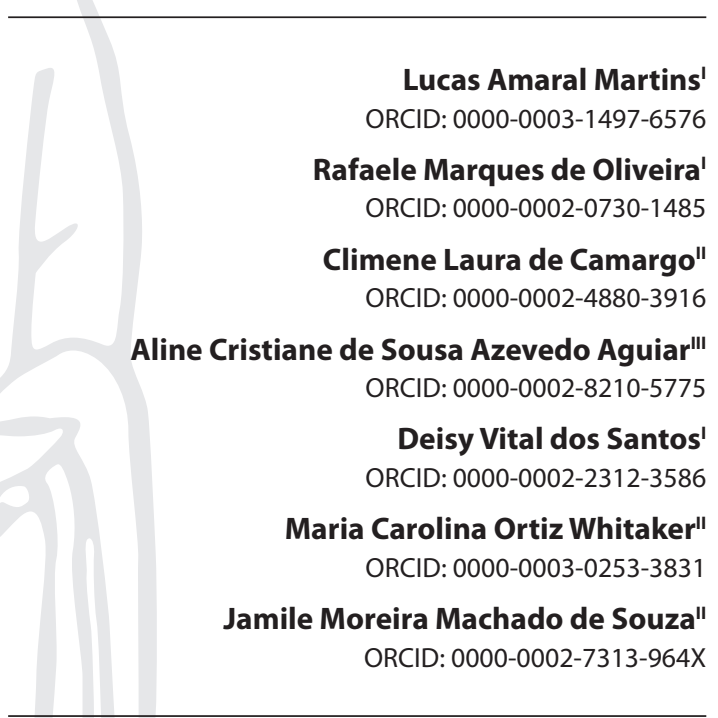

'Universidade Federal do Recôncavo da Bahia. Santo Antônio de Jesus, Bahia, Brazil.

"Universidade Federal da Bahia. Salvador, Bahia, Brazil. "'Universidade do Estado da Bahia. Guanambi, Bahia, Brazil.

How to cite this article:

Martins LA, Oliveira RM, Camargo CL, Aguiar ACSA Santos DV, Whitaker MCO, et. al. Practice of breastfeeding in quilombola communities in the light of transcultural theory. Rev Bras Enferm. 2020;73(4):e20190191. doi: http://dx.doi.org/10.1590/0034-7167-2019-0191

\section{Corresponding author: \\ Lucas Amaral Martins}

E-mail: lucasmartins31@hotmail.com

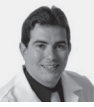

EDITOR IN CHIEF: Antonio José de Almeida Filho ASSOCIATE EDITOR: Dalvani Marques

\section{ABSTRACT}

Objectives: to identify factors that interfere with the practice of exclusive breastfeeding in quilombola communities. Methods: qualitative research based on the Transcultural Theory proposed by Madeleine Leininger, performed with quilombola mothers. For data collection, we used the semi-structured interview, conducted from June 2018 to January 2019. Content analysis was guided by the interactive model of Miles and Huberman. Results: it was revealed that intergenerational cultural myths and customs interfere with breastfeeding practice, and identified the influence of professional nurses on best breastfeeding practices. Final Considerations: cultural and intergenerational factors favor early weaning and expose the child to illness.

Descriptors: Breastfeeding; Child Health; Vulnerable Populations; Transcultural Nursing; Public Policy.

\section{RESUMO}

Objetivos: identificar fatores que interferem na prática de aleitamento materno exclusivo em comunidades quilombolas. Métodos: pesquisa qualitativa fundamentada na Teoria Transcultural proposta por Madeleine Leininger, realizada com mães quilombolas. Para coleta de dados, utilizou-se a entrevista semiestruturada, realizada no período de junho 2018 a janeiro 2019. A análise de conteúdo foi guiada pelo modelo interativo de Miles e Huberman. Resultados: revelou que mitos e costumes culturais intergeracionais interferem na prática do aleitamento materno, e identificou a influência da profissional enfermeira nas boas práticas do aleitamento materno. Considerações Finais: os fatores culturais e intergeracionais favorecem o desmame precoce e expõem a criança ao adoecimento. Descritores: Aleitamento Materno; Saúde da Criança; Populações Vulneráveis; Enfermagem Transcultural; Políticas Públicas.

\section{RESUMEN}

Objetivos: identificar los factores que interfieren con la práctica de la lactancia materna exclusiva en las comunidades de quilombolas. Métodos: investigación cualitativa basada en la Teoría Transcultural propuesta por Madeleine Leininger, realizada con madres quilombolas. Para la recopilación de datos, utilizamos la entrevista semiestructurada, realizada entre junio de 2018 y enero de 2019. El análisis de contenido fue guiado por el modelo interactivo de Miles y Huberman. Resultados: reveló que los mitos y costumbres culturales intergeneracionales interfieren con la práctica de la lactancia materna, e identificó la influencia de las enfermeras profesionales en las buenas prácticas de lactancia materna. Consideraciones Finales: los factores culturales e intergeneracionales favorecen el destete temprano y exponen al niño a la enfermedad.

Descriptores: Lactancia Materna; Salud del Niño; Poblaciones Vulnerables; Enfermería Transcultural; Políticas Públicas. 


\section{INTRODUCTION}

Exclusive breastfeeding (EBF) is considered worldwide to be the best and most complete feeding for children until the sixth month of life. One of the benefits of this practice is associated with the reduction of infant morbidity and mortality. Optimal breastfeeding levels can prevent over 820,000 deaths of children under the age of five worldwide ${ }^{(1)}$, this coupled with the great transformative potential in the growth, development and prevention of diseases in childhood and adulthood ${ }^{(2)}$.

Thus, in an attempt to promote, protect and support breastfeeding throughout the country in 1980, the Brazilian National Breastfeeding Incentive Program (Programa Nacional de Incentivo ao Aleitamento Materno) was launched. This program sought support from health managers at the three levels of government to unify strategies and actions to strengthen and encourage breastfeeding ${ }^{(3)}$. This was followed by the creation of the Brazilian National Policy for Comprehensive Child Health Care (PNAISC Política Nacional de Atenção Integral à Saúde da Criança) in 2015, in which breastfeeding was one of its strategic axes ${ }^{(2)}$.

However, a study reveals that in low - and middle - income countries only $37 \%$ of children under 6 months are exclusively breastfed ${ }^{(1)}$. In Brazil, the exclusive breastfeeding rate is $41 \%{ }^{(4)}$ and is in a worse position compared to all of its Mercosur neighbors except Venezuela ${ }^{(5)}$. Among the Brazilian regions, the Northeast has the lowest prevalence of EBF in children under six months of life, with a percentile of $37 \%{ }^{(4)}$.

Despite the current context, it is noteworthy that breastfeeding indicators have shown an upward trend in the last three decades ${ }^{(6)}$. However, there is a long way to go, especially with regard to the WHO recommendation of at least $50 \%$ of children in $\mathrm{BFE}^{(7)}$.

It is evident that there are still gaps between the programmatic guidelines and the capillarity of breastfeeding policies in the reality of health services, since it is observed that the increments are not homogeneous in all regions of the country ${ }^{(8-9)}$. Thus, in pursuit of equity, PNAISC's actions and strategies aim to provide a better quality of life for developing children, especially for the most vulnerable groups, such as indigenous, quilombola population (A "quilombola" is a resident of a "quilombo" in Brazil, a hinterland settlement founded by people of African origin) and riverine people(9).

These populations exposed to vulnerable conditions, such as quilombola communities, are more likely not to exclusively breastfeed. In the early days of life, thickeners and baby food are introduced because they believe that breast milk is not enough to starve the child ${ }^{(10)}$. A study found that only $28.7 \%$ of quilombola children evaluated received BFE in the first six months of life. However, almost $60 \%$ of infants continued breastfeeding, including other foods, until six months and over ${ }^{(11)}$.

International study confirms findings and points out that mothers of vulnerable groups stop breastfeeding early, even before lactation is fully established ${ }^{(12)}$. Therefore, measures to increase breastfeeding rates in this population are essential(13), considering that existing health services practices do not adequately address the needs of breastfeeding support of these vulnerable populations ${ }^{(12)}$.

This study becomes relevant as it identifies factors that reveal the low adherence of this practice in quilombola communities; elucidate its benefits for reducing child morbidity and mortality and consequently subsidize the actions of health professionals, especially nurses, to promote, protect and support the practice of BFE.

Given experiences, as health professionals and researchers in quilombola communities, it was possible to identify the distance from the implementation of public health policies, especially child health, as well as gaps in scientific production on this theme. This fact made us direct our eyes in order to unveil breastfeeding practices in quilombola communities. Thus, this study sought to answer the following question: What are the factors that interfere with exclusive breastfeeding practices in quilombola communities?

\section{OBJECTIVES}

To identify the factors that interfere with exclusive breastfeeding practices in quilombola communities.

\section{METHODS}

\section{Ethical aspects}

The study complied with the requirements set by national and international regulations governing research involving human subjects. It was submitted and approved by the Research Ethics Committee of Universidade Federal do Recôncavo da Bahia. It was authorized by the leaders of the quilombola communities with consent. A free and informed consent form was prepared and read and signed by the participants. To maintain their anonymity, the names were replaced by letters and numerical sequence from M1 to M24 according to the order of the interviews.

\section{Type of research and theoretical framework}

This is a research with qualitative methodological approach based on Leininger's Theory of Culture Care Diversity and Universality to discuss breastfeeding practices in quilombola communities.

Leininge ${ }^{(14)}$ understands that cultures are the values, beliefs, rites, norms and life practices of a particular group, learned, shared and transmitted in standardized ways. For this theorist, care focuses on the study and comparative analysis of different cultures, in which scientific and humanized knowledge is capable of enabling the practice of universal care. It further adds that humans are cultural beings capable of surviving over time through their ability to care for others in various environments and in many ways.

Considering that culture interferes with BFE practice, the Transcultural Theory allows us to analyze this phenomenon from the perspective of valuing local culture and understanding the practices and values of nursing mothers while breastfeeding their children.

\section{Methodological procedures}

\section{Setting and study participants}

This study was conducted from July 2018 to January 2019 , in three quilombola communities of Bahia. Quilombos are considered the traditional grouping of descendants of slaves who live in a collective space, by means of rules that are consensual to the various family groups that make up the communities, whose 
relations are guided by solidarity backed by cultural values ${ }^{(15)}$. Rapprochement with these communities began in 2008 through teaching-research-extension activities of the Study and Research Group on Child and Adolescent Health at Universidade Federal da Bahia's School of Nursing.

Twenty-four mothers of quilombola children with children aged 0 to 02 years participated in this study. Inclusion criteria were: being native and recognizing themselves as quilombola; being a mother of a NB or child up to 02 years. Exclusion criteria: mothers who did not breastfeed their children and were not found at home for up to three visits during data collection.

The research group has experience in teaching, extension and research with traditional and vulnerable communities, and therefore, before starting data collection, they experienced the study scenario. The invitation to the participants was made by the first author during the group extension activities in the community. After acceptance, date, place and time of interviews were scheduled according to availability of participants. Thus, they were listed for convenience.

\section{Collection procedure and data analysis}

Data collection was performed through semi-structured interviews and field diary. The interview was recorded and held at the participants' homes with an average duration of 25 minutes. The interview was guided by the following questions: tell me about breastfeeding here in the community. Are there factors that interfere with exclusive breastfeeding? Additional data such as: family formation, social, religious bonds, health services were requested to participants to approach and learn about family experiences.

After the end of each interview, individualized feedback with the participant occurred to ensure the collected data's initial impressions. After closing the interviews and analyzing the information, the group of researchers presented the results collectively for the participants to validate (agreeing or disagreeing) the information. Thus, the collection ended by data exhaustion by answering the proposed objective.

Content analysis was guided by the interactive model proposed by Miles and Huberman ${ }^{(16)}$. This model guided the evaluation and interpretation of the data in a dynamic and cyclical process of comings and goings that allowed us to glimpse categories, which constitute the units of analysis.

\section{RESULTS}

The analysis of the information allowed us to delineate four thematic categories called: "The practice of breastfeeding"; "Myths and customs maintained intergenerationally in breastfeeding practices"; "Intergenerational knowledge vs. professional knowledge"; and "The influence of professional nurses on breastfeeding".

\section{The practice of breastfeeding}

BFE is the best way to feed children in the first six months of life and for decades has been encouraged by government and health professionals. The benefits of this practice for both the growth, development and health of the child, for nursing mothers and for the planet. BFE is one of the strategies used worldwide to reduce child mobility. Thus, it is observed that in the communities studied the BFE is also a reality.

\section{[...] he only breastfeeds from the day he was born [...]. (M17)}

[...] she is still breastfed, she started eating food now at 8 months [...]. (M6)

[...] I was able to breastfeed my child for up to six months without adding any other food. (M9)

[...] he just suckled all the time, there was a day that was more than an hour [...]. (M11)

The data from this study revealed that $37.5 \%$ exclusively breastfed their children until the sixth month of life and that $62.5 \%$ introduced some type of food or supplement into the child's diet before the sixth month. It is evident that among the nursing mothers of the quilombola communities studied there are a small number who offer only the breast.

In the interviews and observations recorded in the field diary, it was identified that, in the communities, the introduction of food is cultural, already in the first days of life, configuring as complementary breastfeeding.

[...] only with breast milk, no, he took porridge because at the beginning of my pregnancy my breast milk was little. I gave porridge and breast from the first month of life [...]. (M1)

[...] my milk was not holding is weak, he was hungry and crying, with five days of life I started giving porridge, baby food, boiled banana, and breast milk [...]. (M20)

[...] I give porridge as soon as a fortnight is born [...] one died when I was four months old, gave a diarrhea that didn't cure with anything, then it dried up and God took [...]. (M15)

[...] he prefers porridge because it is breast milk mixed with another substance, I think it fills the belly more. Breastfeeding alone was about eighteen days [...]. (M10)

The statements reveal the vulnerability to which these children are exposed in Brazilian quilombos. It is observed that eating practices can bring health risks and damages, as well as contribute to the increase of child morbidity and mortality in the country. However, for this population, their eating practices are the most assertive, since the introduction of early thickeners and porridge is something natural and culturally accepted by quilombolas, to "starve" and calm children.

Another situation observed was the introduction of food so that the child could sleep longer. Nursing mothers believed that the volume and quality of their milk was not sufficient and adequate to satisfy the hunger of the child. However, it is well known that the composition of breast milk is the most biocompatible for a child's gastrointestinal system even though it needs to be fed at shorter intervals and therefore waking up for longer periods.

Four days old when they cry a lot, they eat porridge, stop crying and sleep well [...]. (M21) 
[...] he sucks, but does not fill his belly, he would open his mouth crying, then I would take and give porridge with rice and milk nest, and he would be quiet and sleep [...]. (M22)

It is also worth noting that the child's crying is not only caused by hunger, but can be precipitated by other factors such as sleep, cramps, discomfort and the need for warmth. The study reveals the lack of knowledge and unpreparedness of nursing quilombolas to identify care needs of their children. This fact points to the need for capillarization by health professionals regarding child care, in particular, demystifying the factors that interfere with BFE practice.

\section{Myths and customs maintained intergenerationally in breastfeeding practices}

The women of the quilombola community value the teachings of matriarchs when breastfeeding their children. Although many of them have access to other means of information, such as television, the Internet, and professional health guidance, they maintain the perpetuated traditions and customs in the community about breastfeeding.

[...] my mother-in-law took care of my protection, taught me that she has to breastfeed in the dark because in the light the milk gets weak and the child goes hungry [...] there is also corn that I have to eat every day and porridge [...] there was a time when I had to go out in the sun and when I came back l expressed my breast and the milk was like water, I had to mix the milk with arrowroot and yam to give the boy if he was not going to die dry. I know a child who died because of it [...]. (M10)

[...] here in quilombo you have a lot of respect for traditions and customs. I tried to respect as much as possible, but everything within my limit and as far as I thought was healthy for me and the baby [...] at two months my grandmother wanted to give thick to fat, she found my daughter thin and did not gain weight and this was because my milk was weak [...] I spoke to her to wait until she was four months old, that's when I left her she gives porridge [...]. (M12)

It is noticeable, in the above speeches, respect for beliefs and customs that are built by various representative rituals, which are based on an event capable of making action, thought and behavior situationally true. In the family context, the traditions and culture of a family, of a people are maintained, even if there are divergent thoughts, as there is respect for traditions above all circumstances.

The practice of cross-breastfeeding in the community was also identified, as reported by $\mathrm{M} 24$.

[...] when they are born, they already want breast, then the mother has to give [...] when there is another woman breastfeeding, we take them [...] they give the breast until the mother's milk arrives [...]. (M24)

This act for many years has been discouraged and contraindicated by WHO and Ministry of Health, due to the risk of vertical transmission of infectious diseases, such as HIV and HTLV, among others that can be transmitted by human milk.

It is also evident how the sociocultural context influences the way women act and think the puerperal pregnancy period.
It is observed that, in the quilombo reality, in addition to predominating myths and beliefs, the act of breastfeeding has family intergenerational influences such as: use of teas and "war meal".

I never gave him any food, just tea and water because it was too hot and he was sweating too much [...] I give him tea because of colic [...] is customary here in the community [...]. (M11)

[...] I gave her water and a cup of tea to clean the belly of the rest [...] because it is tradition [...]. (M13)

In all quilombola communities studied, there was consensus on the introduction of "war meal" in children's diets, a practice that has been used traditionally since the Brazilian colonial period to "kill hunger", have a peaceful sleep and fatten the children. Flour causes the food to be more slowly digested, satisfying the hunger of the child for a longer time. However, it is noteworthy that this eating practice is not nutritious as it does not provide the nutrients necessary for the healthy growth of the child.

The tradition was [...] porridge, my mother made for my girl. (M2)

[...] the other two children I gave thickened with flour and they slept all night [...] my mother always told me that it is good to fatten the child. (M13)

I take the poached fish, make a scraped saucer from the pan with the fish [...]. (M6)

Quilombos are also safeguarded by the nourishing woman, who values habits, customs and beliefs about foods to be eaten for the satisfactory production of breast milk, so as to provide adequate nutrition for her child. Thus, they revealed that their diet is the basis of corn and cassava derivatives, a high-energy food supplemented with high-fat foods.

[...] I was able to do exclusive breastfeeding for up to six months, because my grandmother said I needed to eat a lot of corn and mocotó broth [mocotó is a Brazilian dish made from cow's feet, stewed with beans and vegetables] that gets milk [...] / did it and I had a lot of milk [...]. (M9)

[...] here we eat things from the earth, wahoo, a lot of corn that is good to get milk [...]. (M13)

Here at quilombo is always spoken to eat strong things to get a lot of milk and not leave the child hungry [...] such as corn porridge, cassava porridge, mocotó and feijoada [Feijoada is a stew of beans with beef and pork, which is a typical Portuguese dish] almost every day, to be able to withstand breastfeeding [...]. (M15)

This category reveals that breastfeeding is a universal act, but its practice is diversified and influenced by different cultures. Health professionals' knowledge, especially nurses, becomes fundamental for the development of care practice. Thus, the Transcultural Theory emphasizes that nursing should develop care for people according to their cultural values and their healthdisease context, thus showing the need for nurses to work from the perspective of cultural care. 


\section{Intergenerational knowledge vs. professional knowledge}

The overlap of popular knowledge to the detriment of professional knowledge in quilombola communities has revealed itself significantly. Quilombola nurses demonstrate acting in the perspective of preserving their beliefs, customs and traditions, a fact that makes them resistant to new learning and external influences. Intergenerational and cultural knowledge is strong within a society, a fact that hinders actions and guidance of health professionals in promoting, encouraging and supporting BFE.

[...] the nurse spoke to give only breast milk [...] but he was crying a lot and I gave thickening flour, because my mother said that always took care of her like this, everything is healthy [...]. (M23)

[...] the nurse told me a lot of things there, but I raised my seven children that way, with thickening, and it always worked, it is not now that I will change [...]. (M10)

[...] my mother always gave us fish porridge ]this dish can be perceived as a Brazilian style porridge: its simple ingredients list fundamentally needs only water, cassava flour, fish, and seasoning $\backslash$, but the pediatrician says she can't give it. It is the tradition! For the Pediatrician cannot, but our mother raised us like this. (M1)

Problems and difficulties of biological or psychological nature may occur during breastfeeding. This requires family support and guidance from health professionals, as these difficulties have the potential to generate anxiety and suffering, with the possibility of precipitating the interruption of breastfeeding.

[...] the health center nurse told me that she would have to breastfeed in a way that was comfortable for the baby and me. But it was no use because I spent the guard with my mother, so she only let breastfeed sitting [...] at dawn I have to get up or sit to give breast [...]. (M9)

[...] the nurse said it was to give only breast, I was two days giving breast to sleep, but the girl was waking up all night hungry, and I had to work the other day, so I could not stand it was the way to give back gum [...]. (M14)

The most obvious difficulties are related to biological issues. They could be minimized with guidance from professional nurses during prenatal care and/or in monitoring child growth and development. This, combined with the alignment of health professionals with knowledge in care context of the families of these communities.

[...] I am a nursing technician [...] but of course we always need more experienced people who have experienced this process, my mother helped me a lot and my grandmother also, as they live here, the exchange of experiences was constant [...]. (M12)

Who taught me how to breastfeed was my mother [...] while protecting her and my grandmother gave tips. [...] / always respected [...] the prenatal nurse told me that until the 6th month was to give only breast milk, but as my grandmother and mother took care of me, I followed their tips [...]. (M9)
[...] the doctor instructed me to breastfeed until I was six months old, but since I was the first child I was very scared and who helped me to take care was my mother [...] then I followed what she said and gave porridge and baby food [...] already raised five children, then had experience [...] thank God everything worked out [...]. (M23)

The support and influence of mothers and grandparents to these nursing mothers are noticeable in the interviews. These figures are significant in children care, which reveals the need to include these people in health education and training programs regarding breastfeeding and child nutrition.

\section{The influence of professional nurses on breastfeeding}

Some nursing mothers adhered to the guidelines of health professionals in good practices of exclusive breastfeeding, indicating that, gradually, these professionals are gaining the trust of nursing mothers and carrying out actions aimed at breastfeeding. The figure of the nurse stands out in the guidelines, counseling and assistance to women in the breastfeeding process.

[...] there were people here from the quilombo who thought my son was thin and kept telling me to give him some industry milk. But I followed what the nurse said [...]. (M11)

[...] in this last son, who is already two months old, I never gave anything, only the breast, because in my prenatal the nurse of the post told me that I could not give other things [...] just breast milk up to six months [...]. (M15)

All health professionals working in vulnerable communities are responsible for avoiding the introduction of complementary foods before the child's sixth month of life, encouraging BFE. It is up to them to perform a closer follow-up with pregnant women and nursing mothers in the prenatal, delivery and postpartum period, in order to establish a bond of trust. When these nursing mothers do not find professional help in breastfeeding their children, they turn to easier ways to meet the child's needs, hence the importance of health professionals, especially nursing, providing the necessary support to prevent early weaning.

[...] the nurse who helped me a lot with the handle [...] taught me why my son had a lot of cramps [...] he couldn't take it right and then wind and cracked my breast. After her tips, he gave a good improvement [...]. (M9)

[...] I was having difficulty breastfeeding [...] I took in the health center [...] the nurse told me that the dark part has to put all in his mouth. Now is he getting better, because right when I came, he wasn't totally sucking [...]. (M4)

The nurse who aims to promote, protect and support the $\mathrm{BFE}$, in the perspective of cross-cultural care in the quilombola community, needs to overcome the walls of the Basic Health Unit. and enter the daily life of nursing mothers in order to immerse themselves in their care practices and support them in the difficulties of breastfeeding. These professionals then need to appropriate cultural knowledge and interpret it in a way that aligns scientific and cultural knowledge in order to strengthen best breastfeeding practices. 
[...] I went to the health center and the nurse explained to me what I was supposed to do and I did it. It was not difficult, quickly he took his breast, in fact right there he already took the breast that was almost all morning sucking and look that he had never done it [...]. (M13)

[...] the health center nurse helped me a lot [...] she came here at home and showed me how I put it on my breast, because I was all injured [...] I was disgusted and didn't even want to breastfeed [...] thanks to your directions my daughter suckled [...]. (M17)

[...] the nurse in the unit I work with promoted a short course for pregnant women [...] accompanied by a leaflet that explained the handle, talked about the positions and benefits of breast milk [...] helped a lot in breastfeeding [...]. (M12)

By observing the statements, we can see the importance of nursing professional participation for the continuation of breastfeeding. They reinforce the importance of practice and help in conducting this act, demystify some myths and remove doubts that may occur before or during breastfeeding, providing more safety and comfort for the nursing mother.

\section{DISCUSSION}

This study reveals the low adherence of quilombola nursing mothers to BFE, confirming the findings of other studies conducted in low-income countries, such as Brazil, especially in the Northeast and in quilombola communities ${ }^{(1,4,11)}$.

International studies have shown that, in developed countries, breastfeeding is still lower among mothers in socially vulnerable conditions, especially black women, revealing that, although breastfeeding has begun, most do not maintain it exclusively ${ }^{(17-19)}$. In Asian and Native Hawaiian and Other Pacific Island (NHOPI) subgroups, it was found that $36.3 \%$ of mothers breastfeed exclusively for at least 8 weeks, with lower rates among black mothers ${ }^{(20)}$.

There are several factors that can influence nursing mothers in social vulnerability not to practice BFE until the sixth month of life and early weaning. They include: the myth that milk is weak/ insufficient to kill a child's hunger is a cultural issue, as every woman has the ability to produce the amount of milk needed to support her child ${ }^{(21)}$. Persistent child's crying after breastfeeding causes the nursing mother to associate her hungry, believing that her milk does not feed the baby sufficiently ${ }^{(22)}$; introduction of age-inappropriate foods, such as thickeners, porridge, water and tea, practices that do not neglect BFE for nursing mothers; mother's lack of knowledge about the importance of BFE; little preparation and encouragement of health professionals to practice BFE; nipple pain and trauma; incorrect grip and improper positioning, practices that predispose to the emergence of breast complications, muscle pain, discomfort for the mother ${ }^{(23)}$; pacifier use and maternal labor ${ }^{(22,24-25)}$.

Although contraindicated by the Ministry of Health, the practice of cross-breastfeeding is still very common in vulnerable communities ${ }^{(26)}$. Quilombola community study revealed that some of the practices adopted by the nursing mothers such as the introduction of thickeners; food in the first days of life; breastfeeding; herbs and teas, among others, are in line with scientific knowledge recommended by experts and the Ministry of Health. They often expose newborns to health-threatening conditions, making them more vulnerable to illness ${ }^{(10)}$.

Some prevailing practices in the feeding of the quilombola child date back to the Brazilian colonial period, since at that time the diet was maintained with breastfeeding and foods thickened with flour and porridge. The use of these foods, guided by both popular and traditional culture, was intended to emphasize overfeeding, as malnutrition was a chronic condition among children at that time ${ }^{(27)}$.

Studies ${ }^{(12,18,28)}$ show that both in Brazil and in other countries around the world, there has been the introduction of complementary feeding before the sixth month of life, which is contrary to WHO recommendations ${ }^{(29)}$. In this age group, the child is not yet physiologically mature to chew, swallow and digest, since his gastrointestinal tract is not ready to receive these foods and make his digestion thus impairing the absorption of some nutrients, such as iron, breast milk ${ }^{(30-31)}$.

Breastfeeding is permeated by beliefs, myths, taboos and cultural customs transmitted intergenerationally by each social group of belonging. International studies point to cultural factors as one of the causes of BFE discontinuity in black women, revealing that among these factors include the legacy of slavery, in which women of African descent served as milkmaids for the children of slaveholders. In response to the low adherence of this black population to BFE practices, interventions were designed and implemented to support and encourage BFE. However, it has been unsuccessful as it does not take into account the specific cultural mechanisms that influence breastfeeding behavior in this black and vulnerable population ${ }^{(19,32)}$.

Cultural factors that predispose non-adherence to BFE among black nursing mothers in socially vulnerable situations are also a reality in the Brazilian territory, confirming the legacy of slavery lived by their parents and culturally transmitted between generations $s^{(10,27,33)}$.

Starting from the understanding that black children are in vulnerable conditions, the actions of managers, health professionals, especially nursing, should pay attention to the multifactorial determinants that interfere with the practice of breastfeeding. They should seek to establish legal and policy guidelines that address social and cultural values, beliefs, health services and working conditions to enable women to breastfeed. Despite the widespread benefits of breastfeeding, this is not an effective practice in many communities ${ }^{(34)}$. Overall, children worldwide are not exclusively breastfed for the first 6 months of life as recommended by $\mathrm{WHO}^{(29,35)}$.

In this context, it is necessary to take measures to increase breastfeeding rates in this population, and thus reach the Healthy People 2020 target of $81.9 \%$ for early postpartum BFE; $46.2 \%$ at 3 months of life and $25.5 \%$ at 6 months of life ${ }^{(17)}$. International studies highlight the need for innovations in strategies and actions to promote, encourage and support breastfeeding, particularly in vulnerable populations. These measures should consider the cultural factors of each population subgroup in order to provide more effective care ${ }^{(13,20)}$.

The findings reinforce the importance and at the same time the need for health professionals, namely nurses to know deeply 
the cultural customs that interfere with BFE in these communities and, thus, guide, assist, support and encourage nursing mothers to breastfeed their children. exclusive mode until the sixth month of life. To this end, these professionals must rescue measures for the cultural preservation, denial or accommodation of care, and sometimes restructure care based on the beliefs and cultures of each individual. This attitude is an important step towards the consolidation of culturally congruent health care, as proposed by Leininger ${ }^{(14)}$. It is emphasized that nurses should be aware of the factors that affect breastfeeding, and some of them may be unique to each nurse, based on their culture ${ }^{(19)}$.

Nurses are an essential part of filling breastfeeding knowledge gaps for nursing mothers as they provide guidance on short- and long-term benefits as well as informing breastfeeding-related problems, giving them a sense of security and encouragement for $\mathrm{BFE}^{(36-37)}$. It is noteworthy that these education and support actions, when initiated during prenatal care, are more likely to make a difference ${ }^{(37)}$. Therefore, it is essential that the nurse has the skills to communicate, promote counseling by helping the nurse make decisions, and listen, support, understand and dialogue with her about the pros and cons of this process ${ }^{(38)}$.

In this regard, it is also evidenced the need to implement public health policies, with regard to Child Health and Black Population Health, in order to sustain their programs and in fact modify the reality of abandonment, inequity and vulnerability. where this population is. It is necessary to ensure the access to health of these quilombola communities, meeting the principles of SUS, seeking horizontality in care and approximation of the reality of the context of this population, in order to implement and implement the programs of the black population and PNAISC (39-40).

Finally, there is a need for health professionals, especially nurses in primary health care, to use innovative practices to consolidate actions and implement Public Health Policies within the SUS. Nursing, in advanced practice, has emerged as an excellent tool for improving health care for populations of greater vulnerability, such as indigenous peoples, quilombolas, rural communities, riverine populations, children, among others ${ }^{(41)}$.

\section{Study limitations}

Conducting this study in a single state is a limitation. However, this fact does not preclude replication in other scenarios, as the factors that interfere with breastfeeding practices may differ depending on the cultural context of the population studied.

\section{Contributions to nursing, health or public policy}

The study contributes to nursing, as these professionals can restructure their strategies and actions with a cross-cultural approach in an attempt to consolidate the PNAISC regarding exclusive breastfeeding. Children around the world are not exclusively breastfed, and the increase in BFE rates will favor the reduction of child mortality in the country and in the world.

\section{FINAL CONSIDERATIONS}

In the studied scenario of quilombola communities, the mothers interviewed $37.5 \%$ exclusively breastfed their children until the sixth month of life, and that $62.5 \%$ introduced some type of food or supplement in the child's diet during this same period.

Factors that led, in this study, the non-implementation of EBF and early weaning are related to cultural practices and intergenerational influences, namely: i) myth that milk is weak/insufficient to starve the child; (ii) introduction of age-inappropriate foods such as thickeners, porridge, water and tea; iii) mother's lack of knowledge about the importance of BFE; iv) cross-cultural performance of health professionals; v) incorrect grip and improper positioning.

Nurses' role in guiding nursing mothers stood out as a beneficial action for breastfeeding practices. However, it is necessary that these professionals take literally the context of these communities so that they can provide culturally congruent health care, as proposed by Madeleine Leininger in her theory.

It was also revealed the incipient implementation of public policies, especially the health of children and the black population in these communities that are marginalized, abandoned and vulnerable, in order to guarantee the equity, universality and comprehensiveness advocated by SUS.

Considering the complexity of the theme, further studies are suggested, in order to unveil the multiple aspects that involve breastfeeding, from the perspective of the Brazilian child's right to life and health.

\section{FUNDING}

This research was funded by the Research Program for SUS (PPSUS (Programa Pesquisa para o SUS)/edital009/2018), with the project entitled "Atenção a Saúde da Criança em Vulnerabilidade Social" by the Bahia State Research Support Foundation (FAPESB - Fundação de Apoio à Pesquisa do Estado da Bahia).

\section{REFERENCES}

1. Victora CG, Bahl R, Barros AJ, França GV, Horton S, Krasevec J, et al. Lancet Breastfeeding Series Group. Breastfeeding in the 21st century: epidemiology, mechanisms, and lifelong effect. Lancet. 2016;387(10017):475-90. doi: 10.1016/S0140-6736(15)01024-7

2. Ministério da Saúde (BR). Secretaria de Atenção à Saúde. Departamento de Ações Programáticas Estratégicas. Política Nacional de Atenção Integral à Saúde da Criança: orientações para implementação. - Brasília: Ministério da Saúde, 2018.

3. Michelotto GM, Lorenzini AC. Correlação entre políticas públicas de incentivo ao aleitamento materno e amamentação: estudo de caso em enfermagem em Florianópolis, uma capital ao sul do Brasil. Saúde Redes. 2018;4(1):117-132. doi: 10.18310/2446-4813.2018v4n1p117-132

4. Queluz MC, Pereira MJ, Santos CB, Leite AM, Ricco RG. Prevalence and determinants of exclusive breastfeeding in the city of Serrana, São Paulo, Brazil. Rev Esc Enferm USP. 2012;46(3):537-43. doi: 10.1590/S0080-62342012000300002 
Practice of breastfeeding in quilombola communities in the light of transcultural theory Martins LA, Oliveira RM, Camargo CL, Aguiar ACSA, Santos DV, Whitaker MCO, et. al.

5. Posenato GL. The Lancet: série sobre amamentação. Epidemiol Serv Saúde. 2016; 25(1): 203-204. doi: 10.5123/s1679-49742016000100022

6. Boccolini CS, Boccolini PMM, Monteiro FR, Venâncio SI, Giugliani ERJ. Breastfeeding indicators trends in Brazil for three decades. Rev Saúde Publica. 2017;51:108. doi: 10.11606/S1518-8787.2017051000029

7. Sousa AM, Fracolli LA, Zoboli ELCP. Práticas familiares relacionadas à manutenção da amamentação: revisão da literatura e metassíntese. Rev Panam Salud Publica. 2013 [cited 2019 Feb 20];34(2):127-34. Available From: https://www.scielosp.org/article/rpsp/2013.v34n2/127-134/pt/

8. Zugaib M. Zugaib Obstetrícia: Parto e puerpério. Barueri: São Paulo, Manole, 2016. p. 488.

9. Branquinho ID, Lanza FM. Saúde da criança na atenção primária: evolução das políticas brasileiras e a atuação do enfermeiro. Rev Enferm Cent O Min. 2018; 8:e2753. doi: 10.19175/recom.v8i0.2753

10. Martins LA. Cuidado ao recém-nascido em comunidade quilombola e a influência intergeracional. [Dissertação]. Escola de Enfermagem, Universidade Federal da Bahia, Salvador. 2014.

11. Ministério de Desenvolvimento Social e Combate à Fome (BR). Secretaria de Avaliação e Gestão da Informação. Departamento de Avaliação e Monitoramento. Cadernos de Estudos Desenvolvimento Social em Debate. Chamada Nutricional Quilombola 2006. Brasília, DF, 2014.

12. MacVicar S, Kirkpatrick P, Humphrey T, Forbes-McKay KE. Supporting breastfeeding establishment among socially disadvantaged women: a meta-synthesis. BIRTH. 2015;42(4):290-298. doi: 10.1111/birt.12180

13. Jefferson UT. Closing the Gap: Breastfeeding Strategies and Vulnerable Populations. West J Nurs Res. 2016;38(5):527-528. doi: $10.1177 / 0193945915620401$

14. Leininger M. Cultural care diversity and universality: a theory of nursing. New York: National League for Nursing Press; 1991.

15. Secretaria Especial de Políticas de Promoção da Igualdade Racial (BR). Subsecretaria de Políticas para Comunidades Tradicionais. Programa Brasil Quilombola. Comunidade Quilombolas Brasileiras - Regularização Fundiária e Políticas Públicas. Brasília, 2012.

16. Miles MB, Huberman M. Drawing valid meaning from qualitative data: toward a shared craft. Educational researcher, 1984.

17. Centros de Controle e Prevenção de Doenças. Amamentação entre crianças americanas nascidas em 2002-2012, CDC National Immunization Survey. 2015. Available from: http://www.cdc.gov/breastfeeding/data/NIS_data/index.htm.

18. Lewkowitz A, Raghuraman N, López J, Macones G, Cahill A. 247: Should the gold standard breastfeeding measure in socioeconomically disadvantaged (SED) women be breastfeeding continuation, not initiation? Am J Obstetr Gynecol. 2018;218(1):S159-S160. doi: 10.1016/j. ajog.2017.10.175

19. Reno R. Using group model building to develop a culturally grounded model of breastfeeding for low-income African American women in the USA. J Clin Nurs. 2018;27:3363-76. doi: 10.1111/jocn.13791

20. Hayes DK, Mitchell KM, Donohoe-Mather C, Zaha RL, Melcher C, Fuddy LJ. Predictors of exclusive breastfeeding at least 8 weeks among Asian and Native Hawaiian or other Pacific islander race subgroups in Hawaii, 2004-2008. Matern Child Health J. 2014;18:1215 doi: 10.1007/ s10995-013-1355-1

21. Rocci E, Fernandes RAQ. Dificuldades no aleitamento materno e influência no desmame precoce. Rev Bras Enferm. 2014;67(1):22-27. doi: http://dx.doi.org/10.5935/0034-7167.20140002

22. Moraes JT, Oliveira VAC, Alvin EAB, Cabral AA, Dias JB. A percepção da nutriz frente aos fatores que levam ao desmame precoce em uma Unidade Básica de Saúde de Divinópolis/MG. Rev Enferm Cent O Min. 2014;4(1):971-982. doi: 10.19175/recom.v0i0.446

23. Alves DA, Santos FC, Almeida LA, Mattos MP. Educação em saúde no processo de posicionamento da mãe com o bebê durante a amamentação. Extensão. 2017;16(2):242-52. doi: 10.14393/REE_v16n22017_rel08

24. Lima APC, Nascimento DS, Martins MMF. The practice of breastfeeding and the factors that take to early weaning: an integrating review. J Health Biol Sci. 2018;6(2):189-96. doi: 10.12662/2317-3076jhbs.v6i2.1633.p.189-196.2018

25. Campos AMS, Chaoul CO, Carmona EV, Higa R, Vale IN. Prática de aleitamento materno exclusivo informado pela mãe e oferta de líquidos aos seus filhos. Rev Latino-Am Enfermagem. 2015;23(2):283-90. doi: 10.1590/0104-1169.0141.2553

26. Seehausen MPV, Oliveira MIC, Boccolini CS. Fatores associados ao aleitamento cruzado. Ciênc saúde Colet. 2017;22(5):1673-82. doi: $10.1590 / 1413-81232017225.16982015$

27. Del Priore M. História das crianças no Brasil. 5a. ed. - São Paulo: Contexto; 2012.

28. Organização Mundial da Saúde-OMS. Alimentação de bebês e crianças pequenas: capítulo modelo para livros didáticos para estudantes de medicina e profissionais de saúde afins. Geneva:WHO Press; 2009.

29. Gonsalez PS, Retondario A, Bricarello LP, González-Chica DA, Silva DAS, Vasconcelos FAG. Exclusive breastfeeding, complementary feeding, and association with body fat excess among schoolchildren in Florianópolis, Santa Catarina, Brazil. Rev Bras Saude Mater Infant. 2017;17(1):115-25. doi: 10.1590/1806-93042017000100007

30. Schincaglia RM, Oliveira AC, Sousa LM, Martins KA. Práticas alimentares e fatores associados à introdução precoce da alimentação complementar entre crianças menores de seis meses na região noroeste de Goiânia. Epidemiol Serv Saúde. 2015;24(3):465-74. doi: 10.5123/ S1679-49742015000300012

31. Ministério da Saúde (BR). Secretaria de Atenção à Saúde. Departamento de Atenção Básica. Saúde da criança: aleitamento materno e alimentação complementar. 2. ed. Brasília: Editora do Ministério da Saúde, 2015. 
32. Zamora G, Lutter CK, Peña-Rosas JP. Using an equity lens in the implementation of interventions to protect, promote, and support optimal breastfeeding practices. J Human Lactat. 2015; 31:21-25. doi:10.1177/0890334414561477

33. Pinheiro, CW, Araújo AS, Vasconcelos APN, Freitas DJN, Alencar HCN, Rolim KMC. The care of wet-nurses and the role of blacks in the history of nursing: a fight for fairness. Hist Enferm Rev Eletron [Internet]. 2015[cited 2019 Feb 20];6(1):124-34. Available from: http://here. abennacional.org.br/here/9_AR_01015_MM.pdf

34. Rollins NC, Bhandari N, Hajeebhoy N, Horton S, Lutter CK, Martines JC, et al. Why invest, and what it will take to improve breastfeeding practices? Lancet. 2016;387(10017):491-504. doi: 10.1016/S0140-6736(15)01044-2

35. Cai X, Wardlaw T, Brown DW. Global trends in exclusive breastfeeding. Int Breastfeeding J. 2012;7:1-5. doi:10.1186/1746-4358-7-12

36. Gathron EL. Strategically positioned: breastfeeding, advocacy, and the hands-on nurse. Creative Nurs. 2017;23(3):192-200. doi: 10.1891/1078-4535.23.3.192

37. Demirtas B. Multiparous mothers: Breastfeeding support provided by nurses. Int J Nurs Pract. 2015;21: 493-504. doi: 10.1111/ijn.12353

38. Silva AX, Martins GFR, Cavalcanti MD, França PCG, Silva-Junior AO, Gomes JA. Assistência de enfermagem no aleitamento materno exclusivo: uma revisão integrativa. Braz J Health Rev [Internet]. 2019 [cited 2019 Feb 20];2(2):989-1004. Available from: http://www.brjd. com.br/index.php/BJHR/article/view/1282/0

39. Marques AS, Freitas DA, Leão CDA, Oliveira SM, Pereira MM, Caldeira AP. Primary Care and maternal and child health: perceptions of caregivers in a rural 'quilombola' community. Ciênc saúde Coletiva. 2014;19(2):365-71. doi: 10.1590/1413-81232014192.02992013

40. Siqueira SMC, Jesus VS, Camargo CL. The therapeutic itinerary in urgent/emergency pediatric situations in a maroon community. Ciênc Saúde Coletiva. 2016;21(1):179-89. doi: 10.1590/1413-81232015211.20472014

41. Miranda Neto MV, Rewa T, Leonello VM, Oliveira MAC. Advanced practice nursing: a possibility for Primary Health Care?. Rev Bras Enferm. 2018;71(Suppl-1):716-21. doi: 10.1590/0034- 